\title{
Intelectuais, livros e política: Schmidt Editor e José Olympio Editora na divulgaçáo do Integralismo
}

\author{
Alexandre Pinheiro Ramos*
}

\section{RESUMO}

$\mathrm{O}$ artigo busca analisar o papel desempenhado pelas relaçóes entre o fundador da Ação Integralista Brasileira, Plínio Salgado, e os editores José Olympio e Augusto Frederico Schmidt na publicação e divulgação dos livros integralistas. Em um primeiro momento, procura-se compreender a importância que o livro teve para o Integralismo, visto que entre os anos de 1933 e 1937 os intelectuais da AIB lançaram quase cinquenta títulos, sendo a maior parte publicada pela editora José Olympio e pela Schmidt Editor. Argumenta-se, em seguida, que a dinâmica entre amizade, interesses (materiais e ideias) e relaçóes de poder construída a partir do relacionamento de Plínio Salgado com aqueles dois editores foi decisiva para a publicação das obras integralistas, garantindo sua presença no mercado editorial brasileiro e a circulação das ideias da AIB.

Palavras-chave: Integralismo; Plínio Salgado; José Olympio; Augusto Frederico Schmidt; Livros no Brasil (década de 1930).

\section{ABSTRACT}

The paper seeks to analyze how conviviality between the founder of the Brazilian Integralist Action (AIB), Plínio Salgado, and the publishers José Olympio and Augusto Frederico Schmidt contributed to the publication of Integralist books. First, it tries to ascertain the relevance of books to Integralism, since the intellectuals from AIB published almost fifty books between 1933 and 1937, most of them through two publishing houses: Editora José Olympio and Schmidt Editor. Then, it argues that the dynamics between friendship (material and ideological), interests, and power relations, built by the Salgado's relationship to those two editors, was crucial to the publication of the Integralist works, assuring their presence within the Brazilian publishing market and, thus, the circulation of AIB's ideas.

Keywords: Integralism; Plínio Salgado; José Olympio; Augusto Frederico Schmidt; books

DOI - http://dx.doi.org/10.1590/2237-101X016031012

Artigo recebido em 25 de outubro de 2014 e aprovado para publicação em 27 de março de 2015.

A pesquisa contou com o apoio da bolsa de pós-doutorado vinculada ao PNPD Institucional da Capes. O artigo é uma versáo modificada e ampliada do subitem 2.1.1 de minha tese de doutorado.

* Doutor em Sociologia pela Universidade Federal do Rio de Janeiro (UFRJ). Rio de Janeiro, RJ, Brasil. E-mail: alexandre1337@yahoo.com.br. 
in 1930's Brazil.

Ensinar aos que sabem ler a possuir a sua estante, a adquirir livros, a meditá-los, a anotá-los, a estimar os seus volumes como a amigos. Há casas de homens formados, de funcionários, de professores, de letrados, onde não se vê uma estante, um livro!

Plínio Salgado

Quem olhar a Ação Integralista Brasileira (AIB) para além de seus uniformes, símbolos, saudaçôes, desfiles e marchas, em suma, de toda uma estética próxima dos totalitarismos nazista e comunista, ou sem as limitaçóes de um enfoque que privilegia apenas sua atuação política stricto sensu, encontrará neste movimento de exígua duração (pouco mais de cinco anos), mas que contou com expressivo apoio da população em praticamente todo o território nacional, eventos e açóes obliterados pela pouca atenção concedida ao seu enraizamento no solo sobre o qual atuou, o Brasil, e aos atores diretamente envolvidos. Se de um lado a ênfase no caráter "fascista" do Integralismo impediu que se explorasse com maior acuidade uma série de influências - a partir do contexto intelectual brasileiro - que concorreram para compor as ideias e valores que defendiam e orientavam seu modo de agir, por outro, os esforços para uma compreensão deste movimento, sob o ponto de vista de sua organização nacional, careceram de maior atenção sobre os indivíduos e suas açôes conjuntas e regulares que permitiram a AIB expandir-se por todo o país. ${ }^{1}$

Se, de um punhado de intelectuais e estudantes que se reuniam em uma sala do Clube Português, na cidade de São Paulo, o Integralismo se tornou um movimento de massas de penetração nacional, trazendo em suas fileiras homens e mulheres, jovens e idosos, operários, funcionários públicos e trabalhadores liberais, militares e religiosos, isto foi possível pelas açôes constantes dos militantes, pelas redes de sociabilidade e interações que viabilizaram seu desenvolvimento, organização e funcionamento em nível nacional e local. Igualmente, tal sucesso deu-se pela intensa divulgação e reprodução das ideias integralistas e dos valores que abraçavam. Para tanto, a AIB utilizou-se de uma ampla rede de bens culturais formada por livros, jornais, revistas e conferências que viriam a tornar o Integralismo cotidiano, fa-

\footnotetext{
${ }^{1}$ Busquei, em minha tese, superar estas duas ordens de problemas. Cf. RAMOS, Alexandre Pinheiro. Intelectuais e carisma: a Ação Integralista Brasileira na década de 1930. Tese (Doutorado em Sociologia) Programa de Pós-Graduação em Sociologia e Antropologia, Universidade Federal do Rio de Janeiro, Rio de Janeiro, 2013.
} 
zendo com que ele se tornasse parte da vida dos militantes.

Para os objetivos deste artigo, interessa-me tratar um dos elementos desta rede de bens culturais, o livro integralista. Até o ano de 1937 os intelectuais da AIB publicaram quase cinquenta livros, sendo a grande maioria voltada para o Integralismo. Isto significa dizer que, dentre este total aproximado, havia obras menos diretamente ligadas ao pensamento integralista, como as incursóes de Miguel Reale pela teoria política, a produção literária de Plínio Salgado ou livros de história de Gustavo Barroso. Decerto que não se pode esquecer o fato de que tais obras figuravam na Bibliografia Integralista (lista produzida pela AIB contendo os títulos indicados para a leitura dos militantes), ou mesmo que foram produzidas no contexto de sua atuação no interior do movimento. Porém, mesmo que não se leve isto em conta e considerando-se que o primeiro livro foi lançado em 1933 e os últimos em 1937, quando a AIB foi dissolvida por Getúlio Vargas, ainda assim há um número nada desprezível de obras publicadas em um curto espaço de tempo.

Deste modo, pretendo, em um primeiro momento, compreender as razóes para tal esforço, ou seja, por que os intelectuais integralistas escreveram tantos livros? Qual o sentido desta ação? Parece-me relevante mostrar como o Integralismo esteve presente, em considerável volume e regularidade, no mercado editorial brasileiro. Em outras palavras, isto significa sublinhar o enraizamento da AIB ao contexto nacional e sua situação, neste caso específico, de interpendência em relação a outros atores (na forma de editores, editoras, livrarias). Em seguida, analisarei a relação estabelecida entre os livros integralistas e as principais editoras a publicá-los, Livraria José Olympio Editora e Schmidt Editor, por meio das interaçóes do fundador e um dos principais intelectuais da AIB, Plínio Salgado, com os editores José Olympio e Augusto Frederico Schmidt. Esta ligação já foi apontada por trabalhos como o de Edgard Carone sobre a "Coleção Azul”" e, especialmente, de Gustavo Sorá, ${ }^{3}$ de modo que minha intenção será contribuir para essas análises atentando para algumas das particularidades do contato entre esses três personagens à luz de documentos encontrados durante minha pesquisa no Fundo Plínio Salgado. ${ }^{4}$ Busco, assim, demonstrar como essas editoras contribuíram largamente para a divulgaçáo do Integralismo.

Começarei com uma breve exposiçáo sobre a importância dos intelectuais e dos livros para a Ação Integralista Brasileira e, em seguida, apresentarei alguns números referentes à publicação das obras integralistas. Para tanto, optei por um recorte bem delimitado no

\footnotetext{
${ }^{2}$ CARONE, Edgard. "Coleção Azul”: uma crítica pequeno-burguesa à crise brasileira. Revista Brasileira de Estudos Políticos, Belo Horizonte, n. 25/26, p. 249-296, 1968/1969; Notícias sobre "Brasilianas". Perspectivas, Araraquara, ano 1, v. 1, p. 207-213, 1976.

${ }^{3}$ SORÁ, Gustavo. Livraria Schmidt: literatura e política. Gênese de uma oposição elementar na cultura brasileira. Novos Estudos, São Paulo, n. 61, p. 131-146, 2001; Brasilianas: José Olympio e a gênese do mercado editorial brasileiro. São Paulo: Edusp, Com-Arte, 2010; A arte da amizade: José Olympio, o campo de poder e a publicação de livros autenticamente brasileiros. Antropolítica, Niterói, n. 30, p. 49-71, 2011.

${ }^{4}$ Depositado no Arquivo Público e Histórico do Município de Rio Claro (SP).
} 
qual identifico tal importância em relação ao contexto intelectual brasileiro, sugerindo uma continuidade (e por que não radicalizaçâo?) de algumas ideias circulantes nas décadas anteriores. Com isso pretendo unicamente localizar e introduzir a questão que será trabalhada posteriormente: as relaçóes de Plínio Salgado com Schmidt e Olympio, e o modo como elas afetaram a circulação e a presença dos livros da AIB no mercado editorial brasileiro. Pretendo mostrar como a difusão das ideias integralistas dependeu, em parte, das formas de sociabilidade entre aqueles três agentes, tendo os interesses (materiais e ideais), afetos e amizade exercido um papel crucial neste processo.

\section{Integralismo e os intelectuais}

Quando se atenta para algumas das realizaçóes da AIB na esfera intelectual, como o número e a diversidade de periódicos e livros lançados durante cinco anos, é inevitável a pergunta sobre as pessoas responsáveis por tais produtos culturais. Afinal, não se tratava, sobretudo no caso das várias revistas e jornais editados, de um simples recurso à propaganda. Decerto que tal dimensão estava presente, no entanto, uma produção intelectual volumosa como foi a dos integralistas não teria como se limitar a matérias elogiosas ao movimento. De modo que é possível encontrar um material diverso nas páginas de jornais e revistas: de esquetes cômicos a contos, passando por poesias e piadas, ensaios sobre personagens históricos e folclore, comentários sobre rádio, cinema e teatro, relatos de viagens pelo Brasil feitas por militantes, textos sobre cidades brasileiras etc.

Uma análise do movimento integralista que privilegie os atores envolvidos em sua constituição e atuação - e procure fugir das limitaçóes impostas pela "hipótese fascista" encontrará uma intelectualidade atuando regularmente tanto na produção de bens culturais disponibilizados de modo constante ao seu público quanto por toda a estrutura organizacional da AIB (não custa lembrar que Plínio Salgado, criador do Integralismo e seu grande líder, o Chefe Nacional, era um intelectual, e dos mais ativos no movimento). ${ }^{6}$ Observa-se que vários intelectuais se filiaram à AIB (como Gustavo Barroso, Luiz da Câmara Cascudo

\footnotetext{
${ }^{5}$ Por "hipótese fascista" refiro-me ao argumento que, há 40 anos, a partir do trabalho de Hélgio Trindade (Integralismo: o fascismo brasileiro na década de 30. Rio de Janeiro: DIFEL, 1974) vem sustentando vários estudos sobre o Integralismo, afirmando que ele foi um movimento fascista. A meu ver, o problema maior não reside na hipótese de Trindade, mas sim no modo como ela foi recepcionada, naturalizando-se com o passar do tempo. Tal caracterização cristalizou-se de tal maneira que, acredito, impediu uma maior compreensão de como o contexto brasileiro exerceu enorme influência sobre a criação e a atuação da AIB. Uma reflexão sobre os efeitos da hipótese fascista pode ser lida em: RAMOS, Alexandre Pinheiro. O Integralismo, de Hélgio Trindade, quarenta anos depois: uma crítica à sua recepção. Antíteses, Londrina, v. 7, n. 14, p. 324-347, jul./ dez. 2014. (Neste artigo, assim como em minha tese, utilizei a expressão "tese fascista” em vez de hipótese, termo que parece mais adequado. Mas isto não altera o cerne de minha reflexão.)

${ }^{6} \mathrm{Em}$ minha tese argumento que os intelectuais integralistas tiveram um papel central no desenvolvimento, expansão e organização da AIB no Brasil.
} 
ou Madeira de Freitas, o "Mendes Fradique"), e dentre eles vários jovens que "iniciaram" suas carreiras junto de sua militância (Miguel Reale é, sem dúvida, o maior exemplo, mas também se poderia citar os membros do CAJU, 7 como Hélio Viana ou San Tiago Dantas; e chamo a atenção para a passagem de Guerreiro Ramos, Abdias do Nascimento e Roland Corbisier, que também envergaram a camisa-verde, uniforme dos integralistas). Tem-se, aqui, um primeiro indício para o porquê de o movimento ter apresentado uma produção intelectual volumosa, mas antes de persegui-lo, parece-me importante retroceder às décadas anteriores à criação da AIB para encontrar não somente as razóes para a presença de tantos intelectuais em tal movimento, mas também para sublinhar como as particularidades do contexto brasileiro contribuíram para sua existência. ${ }^{8}$

Os intelectuais no Brasil estiveram, em vários momentos, diretamente envolvidos em esforços de intervenção ou atuação sobre o país, seja pela busca de compreensão sobre seus problemas ou propondo-lhe soluções. Neste sentido, escreve Maria Emilia Prado:

A imensa maioria dos intelectuais ibero-americanos e brasileiros, em especial, não se fecha em torres de marfim. Desde a fundação do Estado em 1822 que os intelectuais brasileiros têm pautado suas vidas não apenas como críticos diante do seu tempo, formadores de cultura ou de opinião pública, mas também atuando como executores de políticas públicas. ${ }^{9}$

O que se verifica, assim, é uma espécie de protagonismo social dos intelectuais, ${ }^{10}$ expresso tanto na formulação de projetos de intervenção com vistas a provocar determinada mudança no seio da sociedade quanto em sua participação em ações diretas, também como executores das ideias propostas. Mas, independentemente do caso, o que se destaca é a visão dos próprios intelectuais brasileiros sobre seu papel e suas funções. Consideram-se, como ilustrado pelos membros da geração $1870,{ }^{11}$ uma nova elite portadora de uma missão: transformar o Brasil, fazê-lo progredir. A construção do Estado e da Nação e a modernização do país passariam, inevitavelmente, pela atuação desses agentes - a intelectualidade da AIB não apenas bebeu desta fonte como radicalizou tal proposta ao articular um movimento nacionalmente organizado com o intento de colocar em prática seu projeto. Tal protagonismo

\footnotetext{
${ }^{7}$ Centro Acadêmico de Estudos Jurídicos, da Faculdade de Direito do Rio de Janeiro. Vários de seus membros filiaram-se à AIB: além de Viana e Dantas, Américo Jacobina Lacombe, Thiers Martins Moreira e Antonio Gallotti se tornaram integralistas.

${ }^{8}$ Relembro que restringirei a exposição a seguir às influências do contexto intelectual brasileiro sobre a AIB. $\mathrm{O}$ que não significa afirmar a inexistência de outros fatores que contribuíram para o surgimento e expansão do movimento.

${ }^{9}$ PRADO, Maria Emilia. Alberto Torres e a responsabilidade do Estado na construção da Naçáo. In: PRADO, Maria Emília (Org.). Intelectuais e ação politica. Rio de Janeiro: Revan, 2011. p. 187-210. p. 188.

${ }^{10}$ Retirei esta expressão de: BASTOS, Elide Rugai; BOTELHO, André. Para uma sociologia dos intelectuais. Dados, Rio de Janeiro, v. 53, n. 4, p. 889-919, 2010.

${ }^{11}$ ALONSO, Angela. Ideias em movimento: a geração 1870 na crise do Brasil Império. São Paulo: Paz e Terra, 2002.
} 
social era arrogado pelos próprios intelectuais, mas a grandeza desta ambição, cultivada a partir dos sentimentos e das tarefas impostas, a si mesma, por uma nova elite comprometida com seu país, talvez só encontrasse equivalente no desgosto e decepção daqueles que seriam seus ilustres membros em relação ao ambiente que os circundava.

No contexto da Primeira República, Farias Brito escrevia que:

Aqui o homem de espírito, o pensador, o artista, é objeto quase de escárnio, por parte dos senhores da situação e dos homens de Estado. Um pensador, um artista, vale para eles menos que uma forte e valente cavalgadura; um poeta menos que uma bonita parelha de carro. ${ }^{12}$

Lamentava-se, assim, o abandono, o esquecimento, a situação de indigência na qual os "homens de letras", amargamente, se encontravam. As perspectivas abertas pela mudança de regime haviam sido frustradas, deixando no lugar aquilo que Nicolau Sevcenko denominou de triplo sentimento de derrota, humilhação e inutilidade. ${ }^{13}$ Contudo, isto não foi capaz de eliminar de vez a ideia do protagonismo social dos intelectuais, arrefecendo o sentimento de que tinham uma missão. Ao contrário, quando, na década de 1920, a frustração diante das promessas não cumpridas da República tornou-se sobremaneira evidente, o desaparecimento das fronteiras entre o homem de letras e o homem de ação, o qual já se processava anteriormente, ganhou novo impulso. A atividade intelectual e a intervençáo sobre a sociedade caminhavam juntas. Aquela funcionaria como instrumento de transformação ou coordenadora dos processos de mudança. Neste sentido, o questionamento da ordem vigente e a proposição de novos caminhos para o país tornavam-se centrais.

Particularmente para os intelectuais, a década de 1920 será de questionamentos inéditos, até então, e que permanecem em pauta pelas próximas décadas. Não apenas concepçôes tradicionais são atacadas, mas também as instituiçôes republicanas — identificadas com uma legalidade que não tem correspondência no real —, elevando o pathos da ruptura, trazendo à tona novos atores e a problemática dos direitos e da participação. ${ }^{14}$

Críticas ao liberalismo e ao sistema oligárquico juntavam-se aos apelos por uma elite nacionalista e a criação de uma consciência nacional. A busca pela brasilidade e a formação de uma identidade brasileira capaz de assegurar a autodeterminação e a soberania do país diante das outras naçóes mesclavam-se, assim, à defesa do Estado (centralizador e unifica-

\footnotetext{
${ }^{12}$ Apud SEVCENKO, Nicolau. Literatura como missão. São Paulo: Brasiliense, 1983, p. 88.

${ }^{13}$ Ibid., p. 92.

${ }^{14}$ LAHUERTA, Milton. Os intelectuais e os anos 20: moderno, modernista, modernização. In: COSTA, Wilma Peres; DE LORENZO, Helena Carvalho (Org.). A década de 1920 e as origens do Brasil moderno. São Paulo: Unesp, 1997. p. 93-114. p. 93.
} 
dor, sobrepondo-se à estrutura "clânica" do país) como meio para a construção da nação e modernização do Brasil. Desta forma, ideias de cunho nacionalista e autoritário, largamente refratárias à ordem vigente, ${ }^{15}$ desenvolveram-se com visível pujança.

A Ação Integralista Brasileira foi, assim, fruto desta "tradição" intelectual, iniciada ainda na Primeira República e cujos efeitos foram sentidos na década de 1930. Particular em seu caso foi o caráter radical que assumiu, pois seus intelectuais foram capazes de organizar não só aquelas ideias e propostas vigentes no Brasil e desenvolver um projeto de intervenção e transformação nacional sustentado por uma "doutrina" que encerrava algumas delas, mas também de articular uma intelectualidade e, posteriormente, uma massa de pessoas em um movimento que se pretendia a colocar em prática tal projeto, realizando-o em sua plenitude. O protagonismo social dos intelectuais assumiu, assim, um novo patamar, pois a nova elite que eles formavam estava empenhada em ser um agente efetivo no processo de transformação nacional - os intelectuais integralistas propunham o caminho a seguir e guiavam as pessoas no interior de uma estrutura organizacional sobre a qual eles exerciam controle e domínio. Não se tratava mais de, unicamente, apontar que o Brasil necessitava de um Estado forte capaz de organizar a sociedade e forjar a nacionalidade: os intelectuais da AIB tomaram para si a tarefa de construir este Estado, de fazer parte de seus quadros político-administrativos, bem como de erigir uma identidade e cultura nacionais mediante sua atuação constante na esfera intelectual. Seu projeto de intervenção tinha seu desenvolvimento e execução atrelados à ação da intelectualidade. $\mathrm{O}$ desprezo, apontado por Farias Brito, com o qual sofriam pensadores e artistas por parte dos "senhores da situação e dos homens de Estado" estaria com os dias contados, pois logo aqueles se transformariam nestes. ${ }^{16}$ As pala-

${ }^{15}$ Escreve Maria Teresa Aina Sadek sobre o pensamento brasileiro na Primeira República: "O que parece incontestável é que se assistia naqueles anos a uma oferta abundante e a uma demanda muito significativa das teorias antiliberais. As doutrinas anti-iluministas, anti-individualistas, anti-utilitáristas exerceram forte influência nas elites intelectuais brasileiras [...]. As instituiçóes republicanas deveriam ser atacadas porque eram responsáveis pela autonomia das regiôes, pelo sufrágio universal, pelo sistema de partidos. Estes traços, cada um a seu modo, tornavam impossível que se buscasse a unidade nacional, o interesse geral acima das facçôes." SADEK, Maria Teresa Aina. Machiavel, Machiavéis: a tragédia Octaviana. São Paulo: Símbolo, 1978, p. 82-83.

${ }^{16} \mathrm{O}$ que singularizou a AIB como um movimento do qual faziam parte pessoas ligadas às atividades intelectuais, aos esforços de pensar (e transformar) a realidade nacional, foi inspirar-se no fascismo em vista das afinidades eletivas entre algumas ideias e objetivos dele e do Integralismo. Com isto quero dizer que o fascismo foi instrumentalizado para dar forma a uma organizaçáo capacitada a executar os ideais integralistas em todo o país. Os debates e questôes em voga no Brasil (a transformação da ordem vigente, o papel do Estado, a reforma moral, a identidade nacional) encontraram em aspectos do movimento fascista (a mobilização das pessoas, a estética, o recurso ao simbólico) um veículo para sua difusão e reprodução junto aos militantes e ao restante da sociedade. A incorporação do fascismo pela AIB foi, assim, reflexiva, mobilizando-se intencionalmente aquilo que poderia contribuir para a estruturação do movimento e, talvez até mesmo, o que possuiria de "promissor" aos olhos dos camisas-verdes, pois sua penetração crescente na Europa poderia reproduzir-se em solo brasileiro. Deste modo, o recurso dos integralistas a aspectos do fascismo europeu deu-se, antes, pelo contexto da sua experiência (política, intelectual, social), o qual deu sentido a tal escolha. Em um quadro de crítica ao modelo liberal, o que estava disponível, fora do Brasil, eram os modelos autoritários comunista e 
vras de Mário de Andrade, em 1932, parecem traduzir muito bem os sentimentos e posturas adotadas pela intelectualidade integralista:

O fenômeno realmente importante e decisivo de nosso realismo foi a fixação consciente do conceito de intelectual... Nós hoje nos debatemos sofridamente ante os problemas do homem e da sociedade, com uma consciência, com um desejo de solucionar, de conquistar finalidade, com um desespero pela posição de fora da lei inerente ao intelectual de verdade. ${ }^{17}$

É bastante ilustrativo deste protagonismo, desta vontade de compreender e intervir no país, uma das finalidades da AIB apontada em seus Estatutos de 1934: "funcionar como centro de estudos de cultura sociológica e política". ${ }^{18}$ A aproximaçáo com a Sociologia não era, decerto, fortuita, pois como escreveu Maria Hermínia de Tavares Almeida:

as Ciências Sociais — em particular a Sociologia — deveriam constituir o ingrediente principal da formação de novas elites, habilitadas a assumir a tarefa de construção política de uma nação moderna [...]. A formação sociológica é contraposta à bacharelesca, timbre das elites tradicionais, responsáveis, em boa medida, pela existência de instituições políticas — de corte liberal — em desavença com as condições do país. ${ }^{19}$

Isto é particularmente importante para mostrar como o movimento retirava do contexto nacional os elementos que o caracterizariam e informariam suas atividades, além de sua própria atualização diante das mudanças ocorridas no país. Afinal, para cumprir seus intentos, era preciso voltar-se não só para a política, mas para a ciência capaz de oferecer meios para transformar e modernizar o Brasil.

\section{O livro integralista}

A produção intelectual integralista foi reflexo direto, por um lado, das mudanças ocorridas na imprensa no início do século XX, como seu barateamento acompanhado das novas técnicas de edição e impressão, além das melhorias implementadas em jornais e revistas,${ }^{20} \mathrm{e}$

fascista. Ou seja, o fascismo de modo algum pode explicar completamente as motivaçóes e açóes dos integralistas, independentemente das semelhanças partilhadas por ambos ao longo do desenvolvimento da AIB. ${ }^{17}$ ANDRADE, Mário de. Aspectos da literatura brasileira. 4. ed. São Paulo: Martins, 1972, p. 49.

${ }^{18}$ SALGADO, Plínio. O Integralismo perante a nação. Rio de Janeiro: Livraria Clássica Brasileira, 1955 [1934], p. 42 (grifo meu).

${ }^{19}$ ALMEIDA, Maria Hermínia Tavares de. Dilemas da institucionalização das ciências sociais no Rio de Janeiro. In: MICELI, Sérgio (Org.). História das Ciências Sociais no Brasil - volume 1. São Paulo: Vértice, Editora Revista dos Tribunais, Idesp, 1989, p. 223-255. p. 189.

${ }^{20}$ Cf. SEVCENKO, Nicolau, Literatura como missáa, op. cit. 
do crescimento do mercado editorial brasileiro, sobretudo a partir de 1930, sob o impacto da crise econômica mundial. ${ }^{21}$ Por outro, do crescente interesse da sociedade pelas questôes brasileiras e dos conflitos entre distintos projetos políticos esposados pelos intelectuais. ${ }^{22} \mathrm{Em}$ relação à imprensa, a AIB contou, entre 1932 e 1937, com aproximadamente 140 periódicos publicados em 19 estados brasileiros, ${ }^{23}$ entre jornais e revistas de circulação nacional e local e com periodicidade variável (diária, semanal, quinzenal, mensal). Sua intensa utilização encontra respaldo nas palavras do integralista Ernani Silva Bruno: ${ }^{24}$

A população alfabetizada do Brasil está, por força das circunstâncias facilmente verificáveis, muito menos em contato com o livro, com a biblioteca, com a conferência educativa, do que com o seu jornal e com sua revista ligeira. [...] o homem do povo das grandes cidades, homem que nunca teve um livro entre as mãos, lê jornal..$^{25}$

Ora, diante de tal constatação de um secretário nacional do movimento, por que livros integralistas continuaram sendo lançados? Afinal, não só as bases do Integralismo já haviam sido lançadas entre 1932 e $1934^{26}$ como existia um esforço maciço pelo uso da imprensa. Mas o que se verifica é o aumento de intelectuais publicando livros: entre 1935 e 1937 o número de autores integralistas mais do que quadruplicou, passando de quatro para dezessete, ao todo. Decerto esse crescimento atrelava-se à expansão da própria AIB pelo país, atraindo um número cada vez maior de militantes (entre eles, outros intelectuais), porém, ainda assim, não deixa de causar algum espanto tal aumento, permitindo que o movimento contasse com quase cinquenta títulos publicados em cinco anos. No entanto, é preciso sublinhar que nem todos foram de material inédito, sobretudo os de Plínio Salgado. Muitos livros do Che-

${ }^{21}$ Cf. OLIVEIRA, Lucia Lippi. Elite intelectual e debate político nos anos 30. Dados, Rio de Janeiro, n. 22, p. 75-97, 1979; MICELI, Sérgio. Intelectuais à brasileira. Rio de Janeiro: Companhia das Letras, 2001.

${ }^{22}$ Como escreve Heloísa Pontes: "Os intelectuais, cingidos pelas ideologias políticas e religiosas do momento, numa polarizaçáo aguda entre os que optaram pelo comunismo e pelo fascismo, e praticada de uma maneira que antes era excepcional, se lançaram tanto no debate dos problemas políticos mais imediatos do país, como se voltaram para a investigaçáo e estudo de nossa realidade". PONTES, Heloisa. Retratos do Brasil: editores, editoras e "coleçóes brasiliana" nas décadas de 30, 40 e 50. In: MICELI, Sérgio (Org.). História das Ciências Sociais no Brasil — volume 1, op. cit. p. 359-409. p. 365.

${ }^{23}$ Mais precisamente, foram 138 títulos. Cf. ENCICLOPÉDIA do Integralismo. Rio de Janeiro: Livraria Clássica Brasileira, 1960. v. X; OLIVEIRA, Rodrigo Santos. Imprensa integralista, imprensa militante. Tese (Doutorado em História) - Programa de Pós-Graduação em História, Pontifícia Universidade Católica do Rio Grande do Sul, Porto Alegre, 2009, p. 138, Tabela 1.

${ }^{24}$ Ernani Silva Bruno se tornou, em 1936, Secretário Nacional de Doutrina e Estudos da AIB, cargo de prestígio antes ocupado por Miguel Reale. Sua declaração citada acima é do período onde já estava na chefia desta secretaria nacional.

${ }^{25}$ Apud BULHÕES, Tatiana Silva. Evidências esmagadoras de seus atos: fotografias e imprensa na construção da imagem pública da Ação Integralista Brasileira (1932-1938). Dissertação (Mestrado em História) — Programa de Pós-Graduação em História, Universidade Federal Fluminense, Niterói, 2007, p. 24-25.

${ }^{26}$ Através de documentos como o Manifesto Integralista de 1932 e, partir de 1933, livros-chave como: Psicologia da revolução e O que é Integralismo, de Plínio Salgado; O estado moderno, de Miguel Reale. 
fe Nacional são compilaçôes de textos publicados na imprensa, alguns inclusive anteriores à fundação da AIB, ou de conferências por ele pronunciadas. O mesmo pode ser dito de outros intelectuais, como Gustavo Barroso ou Viveiros de Castro, que também lançaram obras formadas por conferências apresentadas em núcleos ou reunióes integralistas. Diante disto, reforça-se o questionamento sobre os motivos para a existência deste quadro. A meu ver, uma justificativa pode ser encontrada a partir das reflexôes empreendidas por Max Weber acerca da conjunção de interesses ideais e materiais: "Não as ideias, mas os interesses material e ideal governam diretamente a conduta do homem. Muito frequentemente, as 'imagens mundiais' criadas pelas 'ideias' determinaram, tal qual manobreiros, os trilhos pelos quais a ação foi levada pela dinâmica do interesse". ${ }^{27}$

A AIB nunca escondeu seu intento de travar diálogo, sobretudo nos anos iniciais de sua atuação, com as elites intelectuais do país, visando tirar daí suas principais lideranças e quadros dirigentes e administrativos, de modo que cumpririam papel de extrema relevância para a revolução que o movimento pregava. ${ }^{28}$ Daí Gustavo Barroso considerar o Integralismo "uma concepção totalitária do universo e do homem, tendente a transformar primeiro a alma das élites e em seguida das massas, formando nova consciência e vontade coletiva". ${ }^{29}$ O livro cumpriria um papel de ordem simbólica sob dois aspectos: primeiro, referente à valorização e centralidade das atividades intelectuais no interior do movimento; e segundo, relativo a um "compromisso" entre os intelectuais e seu público.

Para Glaucia Villas Bôas "os livros conjugam, ao mesmo tempo, duas ordens de interesse: conhecimento de determinados problemas, debates de tais problemas". ${ }^{30}$ Os livros integralistas eram, assim, a forma materializada do saber daqueles intelectuais e de suas propostas para a urgente transformação do país. E sua publicação apontava para o interesse de divulgá-las para o público. Fossem nas obras sobre as ideias integralistas ou que abordavam e analisavam questôes relativas à política brasileira, os autores buscavam demonstrar familiaridade com os assuntos tratados, bem como sua capacidade de intervenção nos debates a eles relacionados. O livro apresentava-se como uma espécie de atestado da capacidade intelectual do autor, uma prova de seu conhecimento, da posse de um saber que o diferenciava das outras pessoas enquanto comprovava seu engajamento. Se as imagens e os diagnósticos de uma situação de crise vivenciada no Brasil se refletiam já nos títulos dos livros e nas propos-

\footnotetext{
${ }^{27}$ WEBER, Max. Ensaios de sociologia. Rio de Janeiro: Zahar Editor, 1979, p. 323.

${ }^{28}$ Sobre a ideia de revolução no Integralismo, ver: RAMOS, Alexandre Pinheiro. O Integralismo entre a família e o Estado: uma análise dos integralismos de Plínio Salgado e Miguel Reale (1932-1937). Dissertação (Mestrado em História Política) - Programa de Pós-Graduação em História, Universidade do Estado do Rio de Janeiro, Rio de Janeiro, 2008; e RAMOS, Alexandre Pinheiro. Uma "revolução necessária": o conceito de revolução nos textos dos intelectuais da Ação Integralista Brasileira (1932-1937). Dimensóes, Vitória, v. 26, p. 255-276, jul./dez. 2011.

${ }^{29}$ BARROSO, Gustavo. O Integralismo de norte a sul. Rio de Janeiro: Civilização Brasileira, 1934, p. 53.

${ }^{30}$ VILLAS BÔAS, Glaucia. A vocação das Ciências Sociais no Brasil. Rio de Janeiro: Fundação Biblioteca Nacional, 2007, p. 31.
} 
tas desenvolvidas por seus autores, ${ }^{31}$ significava que eles buscavam, também por este meio, garantir e legitimar suas posiçôes de liderança tanto na esfera da cultura quanto da política. Os intelectuais integralistas atuaram regularmente nesta direção, conjugando pensamento e ação, de modo que chamavam atenção para os esforços intelectuais do movimento: "Temos uma doutrina. Publicamos mais de cinquenta livros, que já atingiram um milhão de exemplares", escrevia Plínio Salgado ${ }^{32}$ com certo exagero. Assim, a AIB gabava-se não apenas de ter ideias (e não apenas interesses políticos imediatos, crítica comum a outros políticos) como também um projeto de transformação de escopo nacional. E o livro se tornou o principal símbolo a corroborar tais afirmações.

Neste sentido, esses intelectuais - sobretudo aqueles em posições de liderança — não podiam simplesmente abdicar de um objeto que poderia conferir-lhes tamanho prestígio e representava a imagem construída e reproduzida pelos próprios (a despeito do fato de que alguns livros tinham caráter panfletário), além de simbolizarem seu engajamento, seu compromisso com aquela sociedade que pretendiam transformar. O livro, assim, aparecia como o resultado do trabalho e dos esforços em prol do país e da construçáo da nação.

Outro motivo para explicar a continuidade da publicação de títulos integralistas seria de ordem econômica: a publicaçáo de um livro permitiria um retorno financeiro, mesmo que não muito elevado, porque haveria um público consumidor "garantido": os próprios militantes da $\mathrm{AIB}$, cujo número aumentava com a expansão do movimento pelo país. Aliás, esta "garantia" pode ser observada, inclusive, nos regulamentos sobre as sedes dos núcleos integralistas: "Toda sede deverá possuir uma pequena biblioteca com todos os livros indicados na Bibliografia Integralista”. ${ }^{33}$ A notícia sobre um núcleo de São Paulo, veiculada no jornal Folha da Manhã de 14 de junho de 1935, mostra que tais indicações não eram ignoradas ou ficavam somente no papel: "A S. M. E. (secretaria municipal de Estudos) já tem organizada uma biblioteca com obras nacionalistas e de autores integralistas. Os interessados devem procurar o companheiro dr. Humberto Silva, na sede social". Pode-se conjecturar que o abastecimento dos núcleos com obras integralistas, já previsto nos regulamentos da AIB, assegurava aos seus autores algum retorno de ordem econômica (ou simbólica). Mas é provável que as principais lideranças intelectuais fossem os maiores beneficiários desse comércio de ideias - isto ficará mais evidente mais à frente.

Antes de avançar, é preciso fazer um brevíssimo comentário sobre as próprias editoras. Gustavo Sorá, ao tratar destas em relação às obras políticas que editavam, afirma que "não se pode comprovar uma adesão doutrinária dos editores a algum dos movimentos políticos da época. Tampouco seria exato atribuir-lhes puros interesses comerciais", pois "as lógicas

\footnotetext{
${ }^{31}$ SADEK, Maria Teresa Aina, Machiavel, Machiavéis: a tragédia Octaviana, op. cit., p. 78; BEIRED, José Luis Bendicho. Sob o signo da nova ordem: os intelectuais autoritários no Brasil e na Argentina (1914-1945). São Paulo: Loyola, 1999, p. 79-86.

${ }^{32}$ SALGADO, Plínio. Páginas de combate. Rio de Janeiro: Ed. Livraria Antunes, 1937, p. 153.

${ }^{33}$ ENCICLOPÉDIA do Integralismo, op. cit. v. XI, p. 96 (grifo meu).
} 
práticas que guiavam o recheio dos catálogos correspondiam às relaçôes pessoais com representantes de uma multiplicidade de posiçóes do campo de poder". ${ }^{44}$ No caso daquelas que mais editaram obras integralistas é possível, assim, verificar uma complexa trama composta não só pela perseguição de interesses comerciais (e ideais), mas também pelas redes de sociabilidade entre os agentes envolvidos e suas relaçóes com o ambiente político e as esferas do poder.

Ora, há um claro relacionamento pessoal, e mesmo de amizade, entre autores e editores que contribui para a escolha das obras (o caso de Augusto Frederico Schmidt, que também tinha seus interesses ideais, é bem ilustrativo, como se verá mais a frente ${ }^{35}$ ). E também há o fator poder, afinal, os editores relacionavam-se com um grupo com evidentes objetivos políticos, com pretensóes de governar (e transformar) o país. Mas a possibilidade de lucro não pode ser descartada, pois diante da maior aceitação do Integralismo, a probabilidade de aumento nas vendas de livros crescia, com alguns títulos alcançando duas ou mais edições. Ou seja, os interesses econômicos — de ambas as partes, frise-se — também concorriam para esta situação, revelando uma multiplicidade de fatores atuantes na possibilidade de divulgaçáo das ideias integralistas nos meios intelectuais brasileiros.

Independentemente, então, do fato de que a imprensa se tornava o meio por excelência de circulação e reprodução do Integralismo em uma escala bem maior, a produção de livros teve continuidade e cresceu com o passar dos anos. Aliás, parece ter havido uma tentativa de aumentar ainda mais o alcance e a oferta dos livros integralistas pela criação de uma "Série Estudos Populares". ${ }^{36}$ Tratava-se de novas ediçôes com preços mais baixos e dimensôes reduzidas. Ora, os livros integralistas custavam, geralmente, entre $6 \$ 000$ e $7 \$ 000$, mas os preços variavam: Psicologia da revolução, de Plínio Salgado, era vendido a 5\$000, O estado moderno, de Miguel Reale, saía por $10 \$ 000$ - de acordo com Laurence Hallewell o preço médio de um "romance normal" era de $6 \$ 000 .{ }^{37}$ Sobre o tamanho, as ediçóes normais tinham, aproximadamente, $12,5 \times 19 \mathrm{~cm}$. Tomando como exemplo, a terceira ediçáo do livro Palavra nova dos tempos novos, de Plínio Salgado (originalmente de 1936), foi publicada em 1937 nesta Série Estudos Populares com o preço de $2 \$ 500$ e tinha, aproximadamente, $10 \times 14 \mathrm{~cm}$.

Imagino que aquelas duas razóes mencionadas acima podem explicar, pelo menos em parte, a regularidade e continuidade na publicação de tais livros. Apresentarei, em seguida, alguns números que poderão dimensionar melhor o volume de obras relacionadas com o Integralismo, as quais circulavam no mercado editorial brasileiro - e neles ficará evidente a predominância das editoras de José Olympio e Augusto Frederico Schmidt, cujo relaciona-

\footnotetext{
${ }^{34}$ SORÁ, Gustavo. A arte da amizade, op. cit., p. 55.

${ }^{35}$ Ver também: SORÁ, Gustavo. Livraria Schmidt: literatura e política. Gênese de uma oposição elementar na cultura brasileira, op. cit.

${ }^{36}$ Foi através de um livro (Palavra nova dos tempos novos, de Plínio Salgado) adquirido durante a pesquisa que tomei conhecimento de tal série (pois fazia parte dela).

${ }^{37}$ HALLEWELL, Laurence. O livro no Brasil (sua história). São Paulo: T. A. Queiroz; Edusp, 1985, p. 317.
} 
mento com Plínio Salgado será abordado depois.

\section{Os livros (de) integralistas em números: autores e editoras}

Apresento, agora, alguns números para que se tenha uma visão, se não exata, a mais completa possível da quantidade de autores e obras integralistas publicadas entre 1933 e 1937, sublinhando a quantidade de editoras que delas se ocuparam nesse período. Não citarei todos os autores, limitando-me a alguns dos principais intelectuais integralistas que lançaram, pelo menos, dois livros.

Dos aproximadamente ${ }^{38} 49$ livros publicados por autores ligados à AIB, 37 foram escritos por apenas cinco intelectuais: Gustavo Barroso, treze; Plínio Salgado, doze; Miguel Reale, sete; Custódio de Viveiros, três; Olbiano de Melo, dois. Os títulos restantes (doze) foram todos escritos por autores diferentes. Como se vê, os três primeiros foram responsáveis por 32 obras — vale lembrar que se tratavam de algumas das maiores lideranças da AIB em nível nacional, compondo a alta cúpula do movimento. No que diz respeito às editoras, foram oito que editaram obras integralistas, sendo as principais: José Olympio, dezoito; Schmidt, dez; Civilização Brasileira, seis; $\mathrm{H}$. Antunes, cinco. O quadro a seguir resume esses números:

Quadro 1: Número de livros publicados pelos autores em cada editora. ${ }^{39}$

\begin{tabular}{|c|c|c|c|c|c|c|}
\hline & $\begin{array}{c}\text { José } \\
\text { Olympio } \\
\text { Editora }\end{array}$ & $\begin{array}{c}\text { Schmidt } \\
\text { Editor }\end{array}$ & $\begin{array}{c}\text { Civilizaçáo } \\
\text { Brasileira }\end{array}$ & $\begin{array}{c}\text { H. } \\
\text { Antunes }\end{array}$ & $\begin{array}{c}\text { Editoras } \\
\text { diversas }\end{array}$ & Total \\
\hline Plínio Salgado & 8 & $3[2]^{40}$ & {$[1]$} & 1 & & 12 \\
\hline Miguel Reale & 5 & 1 & & 1 & & 7 \\
\hline $\begin{array}{c}\text { Gustavo } \\
\text { Barroso }\end{array}$ & 1 & 1 & 6 & & 5 & 13 \\
\hline $\begin{array}{c}\text { Olbiano de } \\
\text { Melo }\end{array}$ & & 2 & & & & 2 \\
\hline $\begin{array}{c}\text { Custódio de } \\
\text { Viveiros }\end{array}$ & 1 & 3 & & 2 & & 3 \\
\hline Outros autores & 3 & 3 & 6 & 5 & 10 & 49 \\
\hline TOTAL & 18 & 10 & & & & 12 \\
\hline
\end{tabular}

${ }^{38}$ Cheguei a estes números não apenas pela consulta direta às obras integralistas, mas também a partir da consulta aos sites da Biblioteca Nacional e da Biblioteca do Congresso dos EUA, e da relação de livros do Fundo Plínio Salgado, depositado no Arquivo Público e Histórico do Município de Rio Claro (SP). Mas é possível que haja outras obras não contabilizadas.

${ }^{39}$ Nesta tabela optei por incluir todos os livros de autores integralistas.

${ }^{40}$ O livro Psicologia da revolução foi publicado, originalmente, pela editora Civilização Brasileira, mas fazia parte da Coleção Azul de Augusto Frederico Schmidt. Os números entre colchetes são para sinalizar isto. 


\section{Plínio Salgado, José Olympio e Augusto Frederico Schmidt}

A distribuição de livros apresentada mostra como as editoras de José Olympio e Augusto Frederico Schmidt exerceram um papel crucial na divulgação do Integralismo ao viabilizarem a publicação de mais da metade das obras dos autores integralistas. $\mathrm{O}$ relacionamento e os laços de amizade mantidos por Plínio Salgado com eles sem dúvida contribuíram para isso. Pretendo, agora, mostrar como os contatos entre o líder integralista e esses dois editores, perpassados pelos interesses materiais e ideias cultivados por eles, tornam-se parte constitutiva da dinâmica do processo de publicação e circulação desses bens culturais. Se na década de 1930 os catálogos das editoras contrabalançavam literatura com obras políticas, acompanhando os questionamentos, reflexóes e projetos dedicados ao país, o que foi traduzido no surgimento de coleçôes específicas, ${ }^{41}$ isto se deu tanto pelo interesse em tais questóes como pela existência de intelectuais dispostos a levar a público suas próprias ideias — intervençôes no debate público que antecediam o desejo de intervir na sociedade. Inicio com a ligação de Plínio Salgado com José Olympio e passo, em seguida, para Augusto Frederico Schmidt.

O relacionamento de Plínio Salgado e José Olympio teve início ainda no tempo da Casa Garraux, onde este trabalhava, quando a livraria era frequentada por personagens proeminentes da vida política e intelectual da cidade de Sáo Paulo - dentre eles estavam os autores modernistas, como Mario e Oswald de Andrade e os principais representantes da vertente verde-amarelo, Menotti del Picchia, Cassiano Ricardo e o próprio Salgado. ${ }^{42}$ Este contato prévio, que remontava à década de 1920, foi retomado já no contexto do Integralismo, tornando-se crucial para a publicação, a partir em 1934, de obras dos autores ligados à AIB, que já estava em franca expansão pelo país. A editora de Olympio publicou, nesse ano, o livro A voz do oeste: romance-poema da época das bandeiras, de Plínio Salgado, mas seu maior empreendimento foi a coleção Problemas Políticos Contemporâneos, que, embora náo exclusivamente, ${ }^{43}$ dedicou-se ao lançamento de vários autores e obras integralistas. Ela contou com, pelo menos, 19 títulos a julgar pela indicaçáo (no 19) no livro Estado corporativo, de Tasso da Silveira, de 1937. A obra que inaugurou a série foi Estado moderno, de Miguel Reale. Vale sublinhar que sua edição contou com a mediação de Plínio Salgado, que não apenas apresentou Reale a José Olympio, mas também assegurou a este a qualidade da obra do companheiro, ${ }^{44}$ o que evidencia a importância das relaçóes interpessoais para a dinâmica do mundo editorial. No mesmo ano Estado moderno ganhou uma segunda

\footnotetext{
${ }^{41}$ Cf. CARONE, Edgard, Notícias sobre "Brasilianas", op. cit.; PONTES, Heloisa, Retratos do Brasil: editores, editoras e "coleçôes brasiliana" nas décadas de 30, 40 e 50, op. cit.; SORÁ, Gustavo. Brasilianas: José Olympio e a gênese do mercado editorial brasileiro, op. cit.

${ }^{42}$ HALLEWELL, Laurence, O livro no Brasil (sua história), op. cit.

${ }^{43}$ Tristão de Ataíde, Cândido Mota Filho e Azevedo Amaral foram outros autores que tiveram livros publicados nesta coleção. Cf. CARONE, Edgard, Notícias sobre "Brasilianas", op. cit.

${ }^{44}$ REALE, Miguel. Memórias: Destinos cruzados. São Paulo: Editora Saraiva, 1987, p. 74.
} 
edição e Reale publicou seu segundo livro na coleção, Formação da política burguesa (nํำ 4), sendo precedido por dois títulos de Plínio Salgado, O sofrimento universal (no 2) e $A$ quarta humanidade (no 3).

A partir daí, a publicação de obras integralistas com o selo da Livraria José Olympio Editora, como parte ou não da coleção, foi aumentando não só na quantidade de títulos (eventualmente com mais de uma edição), mas também de autores, bastando consultar o Quadro 1 - se em 1934 foram, pelo menos, dois autores com cinco livros, entre 1935 e 1937 esses números aumentaram para cinco e treze. Sobre essa produçáo política por parte da José Olympio Editora, escreve Laurence Hallewell:

Talvez a motivação de José Olympio fosse apenas amizade pessoal. Mas, certamente, também pode ter havido um elemento de cálculo comercial, ou até mesmo político. O material tinha mercado garantido e o movimento parecia estar sendo bafejado por favores oficiais e militares. Em 1934, Plínio Salgado proclamava possuir quase 200.000 membros. Em 1937, eram 400.000 membros, com o apoio de 150 revistas mensais e oito jornais diários. ${ }^{45}$

Isto vai ao encontro do que mencionei anteriormente, pois há uma mescla não só de aspectos pessoais que marcam o relacionamento de Olympio com Plínio Salgado, mas também dos interesses econômicos de ambos. O que, por sua vez, vai ao encontro das análises de Gustavo Sorá, quando este escreve que "Desde seu primeiro grande editado, José Olympio misturou o comércio com o afeto, o público com o privado" ${ }^{\$ 4}$ — como ficará ainda mais evidente à frente.

Os documentos encontrados no Fundo Plínio Salgado são ilustrativos da relação que se estabeleceu entre as obras integralistas e a editora de José Olympio, trazendo informaçóes referentes ao valor que o autor receberia e à tiragem de alguns títulos. No que diz respeito a esta, em 1929, mais da metade das obras publicadas contava com ediçóes com menos de 500 exemplares. Na década de 1930 esse quadro alterou-se de forma significativa, com o aumento de livros com tiragens entre 2.000 e 5.000 exemplares, e superiores a $5.000 .{ }^{47}$ Em relaçáo à José Olympio Editora, o número de exemplares (e o preço) dos livros de Plínio Salgado aproximava-se daquele de algumas obras de autores como Humberto Campos e José Lins do Rego. ${ }^{48}$ Por exemplo, $O$ sofrimento universal teve 4.000 exemplares (2.000 para cada edição);

\footnotetext{
${ }^{45}$ HALLEWELL, Laurence, O livro no Brasil (sua história), op. cit., p. 362.

${ }^{46}$ SORÁ, Gustavo. A arte da amizade, op. cit., p. 57.

${ }^{47}$ MICELI, Sérgio, op. cit., p. 151.

${ }^{48}$ A segunda edição de Memórias, de 1933, teve 5.000 exemplares; Moleque Ricardo, de 1935, teve 3.000 exemplares e a segunda edição de Doidinho, também de 1935, teve 4.000. Cf. HALLEWELL, Laurence, $O$ livro no Brasil (sua história), op. cit.
} 
A voz do oeste, 3.000; Despertemos a nação, 6.000; A quarta humanidade, $4.000^{49}$ - o preço de capa ficava entre $5 \$ 000$ e $6 \$ 000$ e Salgado tinha direito a $10 \%$ do valor.

A publicação de obras integralistas parecia, assim, um bom negócio para ambos os lados, pois José Olympio teria um retorno financeiro praticamente garantido com o número crescente de militantes e de interessados no movimento, como ele mesmo atesta, ainda que com ressalvas, em carta dirigida a Plínio Salgado.

O sofrimento universal e Estado moderno vão muito bem; de norte a sul chegam pedidos, o que prova o interesse geral pelo Integralismo. Em S. Paulo é que não vão lá grande coisa. Você não poderia dar um empurrãozinho? Ou santo de casa não faz milagre?.... ${ }^{50}$

Além disso, o movimento e suas ideias ganhavam a divulgação almejada, alcançando o público que mais interessava à $\mathrm{AIB}$ em seus primeiros momentos: as camadas letradas da sociedade brasileira, as quais deveriam fornecer os quadros para a direção do movimento.

Mas parece que José Olympio podia desfrutar um pouco mais de sua relação com o líder integralista. Sabe-se do interesse e do conhecimento de Olympio sobre livros raros e antigos, o que contribuiu para a compra da biblioteca de Alfredo Pujol..$^{51}$ Outra oportunidade que the surgiu foi a aquisição da biblioteca de Alberto Lamego, historiador que se dedicou ao estudo da história do Rio de Janeiro e pai de Alberto Lamego Filho, ${ }^{52}$ que seria um dos primeiros militantes integralistas da cidade de Niterói. ${ }^{53}$ Diante dessa "conjuntura" favorável, José Olympio não hesitou em pedir ajuda a Plínio Salgado, solicitando que este intercedesse em seu favor no tocante à compra da biblioteca. Em carta de 11 de agosto de 1934 na qual enviava um cheque relativo às vendas do livro $O$ sofrimento universal - e tratava do pagamento a Miguel Reale - José Olympio mencionou a intenção de adquirir a biblioteca dos Lamego e pediu a Plínio Salgado que "escreva uma carta ao Alberto Lamego Filho, dizendo-lhe quem é José Olympio”. Por esta carta, descobrimos que uma primeira apresentação já fora feita por outro integralista, Thiers Martins Moreira, o que evidencia um pouco mais do relacionamento entre Olympio e integrantes da AIB, no qual os negócios do primeiro e a política dos segundos mesclavam-se, contribuindo para composição das sociabilidades entre editora e movimento.

\footnotetext{
${ }^{49}$ A quarta humanidade teve uma segunda edição em 1935, mas aquele número parece ser referente apenas à primeira. O livro O sofrimento universal ganhou uma terceira edição em 1936.

${ }^{50}$ Carta de José Olympio a Plínio Salgado: L34.09.27/1.

${ }^{51}$ HALLEWELL, Laurence, O livro no Brasil (sua história), op. cit., p. 348-349.

${ }^{52}$ A principal obra de Alberto Lamego foi $A$ terra goytacá à luz de documentos inéditos, publicada em cinco volumes. Seu filho formou-se em geologia em Londres e escreveu várias obras sobre Geografia Humana abordando, também, o Rio de Janeiro. Cf. VILLAS BÔAS, Glaucia, A vocação das Ciências Sociais no Brasil, op. cit.

${ }^{53}$ FAGUNDES, Pedro Ernesto. A ofensiva verde: a AIB no estado do Rio de Janeiro (1932-1937). Tese (Doutorado em História) - Programa de Pós-Graduação em História Social, Universidade Federal do Rio de Janeiro, Rio de Janeiro, 2009, p. 38.
} 
Este mesmo "favor" foi novamente requisitado em outra carta de José Olympio, de 27 de setembro, onde este diz como Plínio Salgado deveria agir em sua "intervenção" no negócio da biblioteca. Escreveu ele:

Agora, preciso de você para um auxílio muito urgente, e para mim de enorme importância. Recebi ontem a visita do Alberto Lamego, pai, com quem entrei em entendimento a respeito da compra de sua biblioteca. O Lamego e filhos têm por você seu Chefe, como verdadeira veneração (como, ao que parece, todos os integralistas).

O que eu quero de você, Plínio, é uma carta sua, dirigida diretamente ao velho (não ao filho), sem fazer a menor alusão a algum pedido meu neste sentido, mas contando que, tendo recebido uma carta minha a propósito do seu novo livro, soube também que havia recebido a visita do velho com quem me acho em entendimento.

Nessa carta você lhe dirá o que pensa de mim, e o seu nome fará o resto. Saiba que isto tem para mim grande importância, e isto é muito urgente porque pretendo ir a Campos ver os livros até o dia 7 , e preciso que sua carta me preceda.

Veja lá, hein, não vá dar a entender que é carta encomendada e entornar o caldo. Um abraço muito amigo, José Olympio. ${ }^{54}$

Infelizmente não encontrei nenhuma indicação de que Plínio Salgado tenha feito o que foi pedido por José Olympio, mas independentemente do desenrolar desta história em particular, cumpre ressaltar, aqui, a relação estabelecida entre esses dois personagens do microcosmo intelectual e cultural brasileiro, a qual atravessava as esferas política e econômica e provocava seus efeitos diversos no contexto sócio-histórico. José Olympio podia auferir seus lucros e Plínio Salgado garantia a divulgação cada vez maior de seu movimento e de seu projeto. Sem dúvida o contato entre eles incidiu diretamente sobre a possibilidade de os intelectuais integralistas terem suas obras publicadas por uma das mais importantes editoras do país.

Por fim, se José Olympio podia valer-se de seu contato com Plínio Salgado para que este intercedesse a seu favor em um assunto particular, o líder dos integralistas também buscava exercer algum controle sobre as ediçôes dos livros integralistas, "interferindo sobre José Olympio em toda a cadeia de decisóes entre autor e leitor". ${ }^{55}$ Em carta de 20 de maio de 1935 destinada ao editor, Salgado trata da publicação de um livro de Miguel Reale da seguinte maneira:

Agora passemos a um assunto importante para você e o Reale. Acabo de ler o livro dele Introdução à economia moderna. O livro é de uma amplitude universal e a tese desenvolvida,

\footnotetext{
${ }^{54}$ Carta de José Olympio a Plínio Salgado: L34.09.27/1.

${ }^{5}$ SORÁ, Gustavo. Brasilianas: José Olympio e a gênese do mercado editorial brasileiro, op. cit., p. 179.
} 
com os dados estatísticos que contém, com as consideraçóes que faz, com os argumentos sensacionais e, principalmente, do modo como está escrito, claro, fácil, didático, entendo que não deve sair nem com aquele título (que deve ser transformado em subtítulo) e nem na coleção [Problemas Políticos Contemporâneos]. Esse livro é destinado a um sucesso de livraria tão grande como foi o do Gustavo Barroso, Brasil, colônia de banqueiros. Mas esse sucesso depende de um título e de uma capa. O título penso que deve ser como que em réplica ao do Gustavo: $O$ mundo, colônia de banqueiros, com o subtítulo Introdução à economia moderna. A capa deveria ser um globo terrestre envolvido em cadeias de ferro e com as letras por cima, tendo em redor uma fita com as bandeiras de todas as nações. Esse livro feito assim é para ediçôes sobre ediçôes. Colocado na coleção e com aquele título será objeto de um público mais restrito.

Pense sobre isso. E resolvam. É uma opinião minha com olho mais comercial e de propaganda do que cultural. ${ }^{56}$

Aqui, Plínio Salgado interfere diretamente sobre o trabalho editorial, não apenas avaliando o livro — de modo positivo, evidentemente — como fazendo uma série de sugestões, e algumas delas foram seguidas. Por exemplo, o título original foi mesmo transformado em subtítulo, de modo que a obra ficou como $O$ capitalismo internacional: introdução à economia moderna, e ele não fez parte da coleção Problemas Políticos Contemporâneos. Em relação à capa (os títulos daquela coleção tinham capas semelhantes), foi um pouco diferente, porém mantendo o mesmo "espírito" da sugestão de Plínio Salgado: uma teia de aranha com o globo terrestre preso a ela (na porção inferior direita) e uma aranha aproximando-se dele (vindo da parte superior esquerda); no meio, o título $O$ capitalismo internacional.

Antes de prosseguir, faço uma sucinta menção ao caso de Gustavo Barroso, cujo livro de contos $A$ ronda dos séculos foi reimpresso por José Olympio — sendo este seu primeiro lançamento literário ${ }^{57}$ — no ano de 1933, pouco depois de sua escolha para a presidência da Academia Brasileira de Letras. Além deste, O quarto império (obra integralista) também foi publicado por José Olympio em 1935, sendo o nono volume da coleção Problemas Políticos Contemporâneos. Todavia, foi a editora Civilização Brasileira que editou a maior parte dos livros integralistas de Barroso, possivelmente pelo fato nada desprezível de que fora fundada por Barroso junto com o poeta Ribeiro Couto e o livreiro Getúlio Costa. ${ }^{58}$ Além disto, lembro que a primeira edição de Psicologia da revolução, de Plínio Salgado, um dos primeiros livros

\footnotetext{
${ }^{56}$ Carta citada em: SORÁ, Gustavo. Ibid., p. 179. A referência que Plínio Salgado faz ao sucesso do livro de Gustavo Barroso é que Brasil, colônia de banqueiros atingiu cinco edições.

${ }^{57}$ Cf. HALLEWELL, Laurence, O livro no Brasil (sua história), op. cit., p. 351-352.

${ }^{58}$ Cf. ALMEIDA, Marta Assis de. Enio Silveira. Editando o editor 3. São Paulo: Edusp, Com-Arte, 2003. MARIZ, Ana Sofia. Editora Civilização Brasileira: o design gráfico de um projeto editorial (1959-1970). Dissertação (Mestrado em Design) — Programa de Pós-Graduação em Design da Pontifícia Universidade Católica do Rio de Janeiro, Rio de Janeiro, 2005.
} 
sobre o Integralismo, saiu por esta editora, o que mostra como os contatos entre estes agentes e sua circulaçáo pelo ambiente editorial brasileiro contribuíram de maneira decisiva para que os livros integralistas começassem a ser publicados pouco depois da fundação da AIB.

A conexão entre as obras integralistas e a Schmidt Editor deu-se de modo um pouco diferente, pois Plínio Salgado desenvolveu grande relação afetiva com Augusto Frederico Schmidt. O contato entre os dois remontava à São Paulo da década de 1920, nos encontros realizados na pensão da rua Brigadeiro Luís Antônio, onde Plínio Salgado morava e se reunia com outros intelectuais. ${ }^{59} \mathrm{Schmidt}$ teria sido uma das primeiras pessoas a ler o romance de estreia de Salgado, $O$ estrangeiro, de grande sucesso na época. ${ }^{60}$ Além da amizade, afinidades políticas também foram cruciais para a manutenção do relacionamento entre ambos e, consequentemente, para a "contribuiçáa" dada por Schmidt aos intentos de Plínio Salgado. Porque se antes mesmo da fundação da AIB ele já se achava envolvido com os objetivos políticos do futuro líder integralista, foi no contexto do Integralismo que Augusto Schmidt, com sua atuação no mundo editorial, ajudou a divulgar o movimento recentemente fundado. Os dois primeiros livros integralistas de Salgado ( $O$ que é Integralismo e Psicologia da revolução) vieram a lume em 1933 através da Coleção Azul, criada por Schmidt no ano anterior - e ainda em 1933, ele publicaria O Integralismo em marcha, de Gustavo Barroso. Ou seja, a edição das primeiras obras esteve atrelada ao contato muito próximo de Plínio Salgado com Schmidt (amizade entre ambos) e Barroso (atuação na AIB), o que também pode explicar a publicação de $O$ Integralismo em marcha pela Schmidt Editor, mostrando uma rede de sociabilidades que articula desde afetos até atividade política, passando pelos esforços de sensibilização do público para as questōes brasileiras e a "brasilidade". ${ }^{61}$

Como vimos, a editora de Augusto Schmidt foi a segunda maior responsável pela edição de obras integralistas. Se a amizade com Plínio Salgado contribuiu para este primeiro esforço e subsequente empenho em lançar outros livros ligados ao Integralismo, parece que outros interesses ideais também influenciaram tal empreendimento - o que contrasta com

\footnotetext{
${ }^{59}$ RAMOS, Alexandre Pinheiro. Intelectuais e carisma: a Ação Integralista Brasileira na década de 1930, op. cit.

${ }^{60}$ Sobre a recepção do primeiro romance de Plínio Salgado, ver: RAMOS, Alexandre Pinheiro. "Sociologia ou imaginação": aspectos da recepção do livro O estrangeiro, de Plínio Salgado. Revista de Ciências Sociais, Fortaleza, v. 45, n. 2, p. 125-154, jul./dez. 2014.

${ }^{61}$ SORÁ, Gustavo. Livraria Schmidt: literatura e política. Gênese de uma oposiçáo elementar na cultura brasileira, op. cit., p. 144. Vale ressaltar o modo como Sorá analisa as capas e orelhas do livro de Gustavo Barroso, chamando a atenção para o uso delas para a divulgação de obras distintas, porém consideradas sobre certa "unidade": "A sincronização entre os esquemas de percepção do editor, de seus autores e dos leitores possibilitava a reunião de dois mundos que a história separou com a rigidez taxativa de uma divisão entre obras sacralizadas e aquelas deslocadas ao antípoda do profano. A reconstrução desses sistemas de escolhas é fundamental para recuperar significados de época que a história cultural nacional apagou. Se a orelha de O integralismo, de Barroso, era boa para divulgar Casa grande \& senzala, obra de um jovem inédito e promissor, a quarta capa acrescentava um conjunto de edições dissímiles em gênero (romance, poesia, atualidade e doutrina política, ensaio, religião), temas e autores (Ribeiro Couto, Jorge Amado, coronel Leitão Carvalho, padre Leonel França etc.), mas unificadas em torno das ações para sensibilizar sobre a brasilidade,"
} 
a relação com a editora de José Olympio. Vejamos um pouco mais desta dinâmica a partir dos documentos encontrados durante a pesquisa.

No contrato assinado entre Plínio Salgado (representado por Madeira de Freitas, o Mendes Fradique) e a Schmidt Editor para a edição de O que é Integralismo, verifica-se o número de cópias e o valor que caberia ao autor, além das obrigaçóes das partes envolvidas. A editora imprimiria 5.000 exemplares da obra e deveria pagar a Plínio Salgado a importância de 2:500\$000 (dois contos e quinhentos mil réis), equivalente ao valor de $10 \%$ sobre o preço de capa (ou seja, 5\$000). Por sua vez, Salgado não poderia autorizar nova edição até que o livro se esgotasse. ${ }^{62}$ Nota-se que o preço de capa do livro, o número de cópias e o valor pago a Salgado são parecidos com aqueles da José Olympio Editora. Outro dado interessante é que a Schmidt Editor também parecia empenhar-se em fazer propaganda do movimento, contribuindo, assim, para sua divulgação. Dentre vários tópicos abordados em carta da editora (como pagamentos e remessas de livros a Salgado), de julho de 1933, há o seguinte:

PROPAGANDA - A propaganda do INTEGRALISMO está sendo feita com a maior intensidade possível, sendo que se os jornaes pouco têm falado a respeito do mesmo não é por nossa culpa e sim porque estão cheios de matéria e dispóem de pouco espaço. ${ }^{63}$

A AIB não tinha ainda nem um ano de existência, o que explicaria o pouco interesse da imprensa, mas não deixa de chamar a atenção o engajamento da própria editora no projeto integralista, contribuindo para sua divulgação - o que mostra como a expansão do movimento usufruiu dos relacionamentos pessoais, como aquele entre Plínio Salgado e Augusto Schmidt.

Aliás, uma carta do punho deste último revela a profundidade de sua amizade com o líder integralista. Nela, ao comentar o prefácio redigido por Salgado para a terceira edição do livro O que é Integralismo, diz:

Fiquei comovido. Você tem crescido, dia para dia — e tanto — que eu já penso que você não é mais o meu velho amigo de antigamente - o da Av. Brigadeiro Luiz Antonio, o da noite de Natal, que passamos os dois acordados, o dos passeios noturnos pela S. Paulo, da Barra Funda etc.

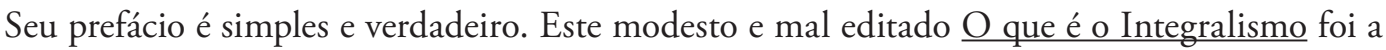
semente do seu, do nosso movimento de redempção.

$\mathrm{O}$ que mais temia nesse movimento era que a lucta me tivesse endurecido o coraçáo. Seu prefácio me mostrou que não.

O gosto da humildade [?], o reconhecimento do passado, e a ternura ainda estáo mais fortes do que nunca no teu coraçáo.

\footnotetext{
${ }^{62}$ Contrato: FPS 027.002.006_1.

${ }^{63}$ Carta da Livraria Schmidt-Casa Editora a Plínio Salgado: CPi 33.07.15-1.
} 
Deus continue a assisti-lo que a sua vida é a mais preciosa vida do Brasil.

Quando vier ao Rio veja se encontra um jeito de se encontrar com seu velho Schmidt. ${ }^{64}$

A referência ao "modesto e mal editado" livro de Plínio Salgado fornece mais indícios de como a proximidade de ambos foi decisiva para a circulação e divulgação do Integralismo, sobretudo no início da atuação da AIB (1933), quando Plínio Salgado encontrou na editora do amigo o primeiro meio para veicular as obras básicas sobre o movimento. Mas o que chama atenção é o comentário de Schmidt que, ao que tudo indica, refere-se ao Integralismo ao falar em "nosso movimento de redençáo" - não há indicaçóes de que ele tenha se filiado oficialmente à AIB.

Em outra carta (cujo destinatário é desconhecido ${ }^{65}$ ) na qual Schmidt trata da reedição do livro $O$ que é Integralismo, ele escreve: "Peço-lhe que se lembre de que desejo reeditar (aliás, a Livraria Schmidt) O que é o Integralismo, do nosso Chefe." E mais à frente: "Não tenho nenhum interesse material nesse negócio, mas desejaria que este livro tivesse o nome da casa que fundei, por motivos puramente moraes, que você compreenderá." Destaco, aqui, a referência feita a Plínio Salgado como "nosso Chefe", que, somada ao "nosso movimento de redenção", mostram um maior e mais profundo envolvimento de Augusto Frederico Schmidt com o Integralismo, pelo menos nos anos iniciais deste. Parece também ser indicativo deste relacionamento sua vontade de reeditar o livro de Salgado sob a alegação de que não tinha "nenhum interesse material nesse negócio". Aliás, é provável que ele estivesse sendo sincero ao fazer tal afirmativa, afinal, o movimento integralista era ainda incipiente, de modo que um eventual retorno financeiro náo estaria garantido (situação diferente das ediçóes publicadas pela Livraria José Olympio). Não é possível saber quais eram seus "motivos puramente morais", todavia, pode-se conjecturar que não era só a amizade que fazia Schmidt abraçar tal empreendimento. Parece que suas afinidades com Plínio Salgado extrapolavam a dimensão da amizade, havendo aí objetivos políticos (interesses ideais) contribuindo para seu envolvimento direto com a AIB.

Outra carta, agora de Plínio Salgado para Schmidt, ilustra como se daria a atuação deste no contexto do movimento, contribuindo para a circulaçáo do Integralismo.

O nosso companheiro, Dr. Raul Stein de Almeida, tem uma livraria em Niteroy, á rua Visconde de Uruguay, 561. Peço-lhe confiar a venda de meus livros naquella cidade. É um dever de solidariedade que, cumprido, só pode redundar em favor do êxito dos livros alli.

\footnotetext{
${ }^{64}$ Carta de Augusto Frederico Schmidt a Plínio Salgado. Pi 33.07.00/1.

${ }^{65}$ De acordo com o Arquivo de Rio Claro, esta carta estaria incompleta, náo apresentando a(s) primeira(s) folha(s). A primeira linha das folhas restantes faz referência ao "querido Madeira de Freitas". Talvez tenha sido este o destinatário, mas não há como ter certeza. Pi 33.00.00/1.
} 
Peço-lhe, também, mandar-me uma certa quantidade de exemplares, para que eu os offereça a imprensa e críticos daqui. Aos dahi, offerecerei ahi mesmo, quando for. ${ }^{66}$

Verifica-se, aí, a iniciativa do próprio Plínio Salgado em divulgar suas obras, mas sublinho o primeiro pedido, pois revela um pouco mais desta dinâmica envolvendo a expansão do movimento e a divulgação das ideias integralistas. Esta carta, escrita em São Paulo, é datada de 21 de junho de 1933 e, de acordo com a pesquisa feita por Pedro Ernesto Fagundes, no princípio deste mês Plínio Salgado esteve em Niterói, onde fez uma conferência sobre o Integralismo no Liceu Nilo Peçanha. Ocorrida no Saláo Nobre, o tema da conferência foi "O que é o Integralismo". Mais tarde, realizou outra:

Poucas semanas depois, mais precisamente em 15 de junho, Salgado esteve na cidade para, novamente no saláo nobre do Liceu Nilo Peçanha, realizar uma segunda conferência. Como reflexo do sucesso de sua primeira palestra, nessa nova passagem por Niterói, Plínio Salgado foi recepcionado por dezenas de milicianos fluminenses devidamente trajados com as inconfundíveis "camisas-verdes". O tema da palestra — que lotou as dependências do saláo nobre — foi a "Exegese da Revoluçấo". ${ }^{67}$

É interessante salientar que os temas seguiram as duas obras fundamentais sobre o Integralismo, sendo bem possível que os livros solicitados por Salgado a Schmidt para serem colocados à venda na livraria fossem, justamente, O que é o Integralismo e Psicologia da revolução. Aliás, seu dono, Raul Stein, compunha o grupo dos primeiros militantes da AIB em Niterói. ${ }^{68}$

Parece-me claro que, pelo número de obras integralistas editadas pela Schmidt Editor entre 1933 e 1937, não se pode desconsiderar a possibilidade de um retorno financeiro pelas vendas, mas neste caso particular, diferentemente da editora de José Olympio (onde o relacionamento com agentes que almejariam posiçóes de poder teria maior relevância), parece haver, lado a lado com a amizade com Plínio Salgado, certo "engajamento" de Augusto Frederico Schmidt no projeto integralista ou, no mínimo, alguma crença naquelas novas ideias e valores apresentados pelo amigo da av. Brigadeiro Luís Antônio.

\section{Conclusão}

O relacionamento de Plínio Salgado com José Olympio e Augusto Frederico Schmidt exerceu um importante papel na publicação dos livros de autores ligados ao movimento

\footnotetext{
${ }^{66}$ Carta de Plínio Salgado a Augusto Frederico Schmidt: L 33.06.21-3.

${ }^{67}$ FAGUNDES, Pedro Ernesto, A ofensiva verde: a AIB no estado do Rio de Janeiro (1932-1937), op. cit., p. 37-38.

${ }^{68}$ Ibid., p. 38.
} 
integralista - e na consequente divulgação e circulação de suas ideias e valores. Em um universo de quase cinquenta títulos publicados entre 1933 e 1937, mais da metade veio a lume por meio daqueles dois editores. Um complexo de fatores contribuiu diretamente para que o mercado editorial brasileiro tivesse uma pequena parcela sua voltada (direta ou indiretamente) para o Integralismo: desde a amizade até o interesse comercial, passando pela atenção às relaçôes de poder e mesmo pelas vantagens que se podia obter em tal relacionamento. $\mathrm{E}$ isto tudo, claro, operando em um contexto no qual as pessoas se interessavam pelas questôes e debates relativos à sociedade brasileira em sua dimensão política, cultural, social. Onde intelectuais que buscavam intervir na realidade social, visando a superação de seus problemas, apresentavam projetos para o país na forma de livros. Se a Ação Integralista Brasileira, notadamente sua intelectualidade, arrogava este direito - e este dever - foi porque se ligava a uma "tradiçấo" de nossos intelectuais, que atuavam tanto na esfera política quanto na cultural, compondo interseçôes entre estas. A diferença é que os integralistas radicalizaram tal "tradição" - não foram, assim, um ponto fora da curva, mas a porção mais acentuada desta, levando às últimas consequências a ideia de intervenção, aproximando-se de uma forma de engenharia social como descrita por Karl Popper:

[A engenharia social ou utópica] Almeja remodelar "toda a sociedade" de acordo com um plano ou projeto definido; visa a "conquistar posiçôes-chave" e a ampliar "o poder do Estado [...] até que o Estado se torne quase idêntico à sociedade". A partir dessas "posiçóes-chave", almeja controlar as forças históricas que moldam o futuro da sociedade em desenvolvimento, seja detendo esse movimento, seja prevendo seu curso e a ele adaptando a sociedade. ${ }^{69}$

Se era este um dos objetivos da AIB, pode-se afirmar que a divulgação e a rotinizaçáo de suas ideias e valores por meio de livros contribuiriam de algum modo para torná-lo real.

Meu objetivo com este artigo foi, em um primeiro momento, apontar rapidamente o vínculo entre a AIB e o conjunto de esforços de nossa intelectualidade para pensar e mudar o Brasil. Mostrei como a ideia do protagonismo social do intelectual foi incorporada pelo movimento (náo é preciso lembrar que foram intelectuais que o fundaram) e que a "crença" nele pode ser verificada no número de livros publicados, na valorização destes para a realização de seu projeto político (e também cultural). Em seguida, utilizando as relaçóes de Plínio Salgado com José Olympio e Augusto Frederico Schmidt, busquei ilustrar algumas características e aspectos da dinâmica do processo de publicaçáo de livros integralistas, mostrando como um movimento político iniciado em outubro de 1932 ganhou espaço, a partir de 1933 e, sobretudo, de 1934, no mercado editorial brasileiro. Atentando para as interaçóes entre esses indivíduos, procurei mostrar como relaçôes afetivas, comerciais e políticas permitiram

\footnotetext{
${ }^{69}$ Cf. POPPER, Karl. Engenharia social gradativa [1944]. In: Textos Escolhidos. Rio de Janeiro: Contraponto, PUC-RJ, 2010, p. 302.
} 
a edição das primeiras obras e o crescimento constante da divulgação e circulação das ideias integralistas. Esses contatos levaram à conformação de um universo de quase cinquenta títulos, de dezessete autores, publicados por nove editoras em cinco anos. Embora não haja como ter certeza, até o momento, se todos os livros foram vendidos, o fato de haver vários títulos com duas edições ou mais depóe em favor da existência de um público que os adquiria.

Para a elaboraçáo deste artigo, centrei-me nos casos de Schmidt e Olympio, em vista dos documentos encontrados no Fundo Plínio Salgado, mas também seria válida uma pesquisa sobre a relaçáo das obras integralistas com a editora Civilização Brasileira, em particular a de Gustavo Barroso - isto fica em aberto. Por fim, com este artigo pretendi retirar o Integralismo de um quase estado tanto de isolamento quanto de esquecimento no qual se encontra nas pesquisas sobre a AIB e sobre a atividade intelectual na década de 1930. Sua presença no mercado editorial mostra sua incontornável presença e atuação naquele momento.

\section{Fontes documentais}

Fundo Plínio Salgado (Arquivo Público e Histórico do Município de Rio Claro - SP)

Carta da Livraria Schmidt-Casa Editora a Plínio Salgado: CPi 33.07.15-1.

Carta de Augusto Frederico Schmidt a Plínio Salgado. Pi 33.07.00/1.

Carta de José Olympio: Pi 33.00.00/1.

Carta de José Olympio a Plínio Salgado: L 34.09.27/1.

Carta de Plínio Salgado a Augusto Frederico Schmidt: L 33.06.21-3.

Contrato: FPS 027.002.006_1.

\section{Referências bibliográficas}

ALMEIDA, Maria Hermínia Tavares de. Dilemas da institucionalização das ciências sociais no Rio de Janeiro. In: MICELI, Sérgio (Org.). História das Ciências Sociais no Brasil volume 1. São Paulo: Vértice, Editora Revista dos Tribunais, Idesp, 1989.

ALMEIDA, Marta Assis de. Enio Silveira. Editando o editor 3. São Paulo: Edusp, ComArte, 2003.

ALONSO, Angela. Ideias em movimento: a geração 1870 na crise do Brasil Império. São Paulo: Paz e Terra, 2002.

ANDRADE, Mário de. Aspectos da literatura brasileira. 4. ed. São Paulo: Martins, 1972. 
BARROSO, Gustavo. O Integralismo de norte a sul. Rio de Janeiro: Civilizaçáo Brasileira, 1934.

BASTOS, Elide Rugai; BOTELHO, André. Para uma sociologia dos intelectuais. Dados, Rio de Janeiro, v. 53, n. 4, p. 889-919, 2010.

BEIRED, José Luis Bendicho. Sob o signo da nova ordem: os intelectuais autoritários no Brasil e na Argentina (1914-1945). Sáo Paulo: Loyola, 1999.

BULHÓES, Tatiana Silva. Evidências esmagadoras de seus atos: fotografias e imprensa na construção da imagem pública da Ação Integralista Brasileira (1932-1938). Dissertação (Mestrado em História) — Programa de Pós-Graduação em História, Universidade Federal Fluminense, Niterói, 2007.

CARONE, Edgard. "Coleção Azul": uma crítica pequeno-burguesa à crise brasileira. Revista Brasileira de Estudos Políticos, Belo Horizonte, n. 25/26, p. 249-296, 1968/1969.

. Notícias sobre "Brasilianas". Perspectivas, Araraquara, ano 1, v. 1, p. 207-213, 1976. ENCICLOPÉDIA do Integralismo. Rio de Janeiro: Liv. Clássica Brasileira, 1960. v. X e XI. FAGUNDES, Pedro Ernesto. A ofensiva verde: a AIB no estado do Rio de Janeiro (19321937). Tese (Doutorado em História) — Programa de Pós-Graduação em História Social, Universidade Federal do Rio de Janeiro, Rio de Janeiro, 2009.

HALLEWELL, Laurence. O livro no Brasil (sua história). São Paulo: T. A. Queiroz; Edusp, 1985.

LAHUERTA, Milton. Os intelectuais e os anos 20: moderno, modernista, modernização. In: COSTA, Wilma Peres; DE LORENZO, Helena Carvalho (Org.). A década de 1920 e as origens do Brasil moderno. São Paulo: Unesp, 1997.

MARIZ, Ana Sofia. Editora Civilização Brasileira: o design gráfico de um projeto editorial (1959-1970). Dissertação (Mestrado em Design) — Programa de Pós-Graduação em Design da Pontifícia Universidade Católica do Rio de Janeiro, Rio de Janeiro, 2005.

MICELI, Sérgio. Intelectuais à brasileira. Rio de Janeiro: Companhia das Letras, 2001.

OLIVEIRA, Lucia Lippi. Elite intelectual e debate político nos anos 30. Dados, Rio de Janeiro, n. 22, p. 75-97, 1979.

OLIVEIRA, Rodrigo Santos. Imprensa integralista, imprensa militante. Tese (Doutorado em História) - Programa de Pós-Graduação em História, Pontifícia Universidade Católica do Rio Grande do Sul, Porto Alegre, 2009.

PONTES, Heloisa. Retratos do Brasil: editores, editoras e "coleçôes brasiliana" nas décadas de 30, 40 e 50. In: MICELI, Sérgio (Org.). História das Ciências Sociais no Brasil — volume 1. São Paulo: Vértice, Editora Revista dos Tribunais, Idesp, 1989.

POPPER, Karl. Engenharia social gradativa [1944]. In: Textos Escolhidos. Rio de Janeiro: Contraponto, PUC-RJ, 2010. 
PRADO, Maria Emilia. Alberto Torres e a responsabilidade do Estado na construção da Nação. In: PRADO, Maria Emília (Org.). Intelectuais e ação política. Rio de Janeiro: Revan, 2011.

RAMOS, Alexandre Pinheiro. Intelectuais e carisma: a Ação Integralista Brasileira na década de 1930. Tese (Doutorado em Sociologia) — Programa de Pós-Graduação em Sociologia e Antropologia, Universidade Federal do Rio de Janeiro, Rio de Janeiro, 2013.

. O Integralismo, de Hélgio Trindade, quarenta anos depois: uma crítica à sua recepção. Antíteses, Londrina, v. 7, n. 14, p. 324-347, jul./dez. 2014.

. O Integralismo entre a família e o Estado: uma análise dos integralismos de Plínio Salgado e Miguel Reale (1932-1937). Dissertação (Mestrado em História Política) Programa de Pós-Graduação em História, Universidade do Estado do Rio de Janeiro, Rio de Janeiro, 2008.

. Uma "revolução necessária": o conceito de revolução nos textos dos intelectuais da Ação Integralista Brasileira (1932-1937). Dimensóes, Vitória, v. 26, p. 255-276, jul./dez. 2011.

REALE, Miguel. Memórias: Destinos cruzados. São Paulo: Editora Saraiva, 1987.

SADEK, Maria Teresa Aina. Machiavel, Machiavéis: a tragédia Octaviana. São Paulo: Símbolo, 1978.

SALGADO, Plínio. O Integralismo perante a nação. Rio de Janeiro: Livraria Clássica Brasileira, 1955 [1934.

. Páginas de combate. Rio de Janeiro: Ed. Livraria Antunes, 1937.

SEVCENKO, Nicolau. Literatura como missão. São Paulo: Brasiliense, 1983.

SORÁ, Gustavo. A arte da amizade: José Olympio, o campo de poder e a publicação de livros autenticamente brasileiros. Antropolítica, Niterói, n. 30, p. 49-71, 2011.

- Brasilianas: José Olympio e a gênese do mercado editorial brasileiro. São Paulo: Edusp, Com-Arte, 2010.

. Livraria Schmidt: literatura e política. Gênese de uma oposição elementar na cultura brasileira. Novos Estudos, São Paulo, n. 61, p. 131-146, 2001.

VILLAS BÔAS, Glaucia. A vocação das Ciências Sociais no Brasil. Rio de Janeiro: Fundação Biblioteca Nacional, 2007.

WEBER, Max. Ensaios de sociologia. Rio de Janeiro: Zahar Editor, 1979. 